\title{
МОВОЗНАВСТВО
}

\section{СТІЙКІСТЬ, ВАРІАТИВНІСТЬ І ТРАНСФОРМАЦІЯ УКРАЇНСЬКИХ ПРИСЛІВ'ЇВ}

\author{
ВАЛЕНТИНА КАЛЬКО \\ Черкаський національний університет імені Богдана Хмельницького, Черкаси - Україна \\ mkalko@ukr.net; ORCID: 0000-0002-9394-1664
}

\section{МИКОЛА КАЛЬКО}

Черкаський національний університет імені Богдана Хмельницького, Черкаси - Україна mkalko@gmail.com; ORCID: 0000-0001-6042-4436

\section{STAŁOŚĆ, ZMIENNOŚĆ ORAZ TRANSFORMACJA UKRAIŃSKICH PRZYSŁÓW}

\author{
WALENTYNA KALKO \\ Czerkaski Uniwersytet Narodowy imienia Bohdana Chmielnickiego, Czerkasy - Ukraina \\ MYKOŁA KALKO \\ Czerkaski Uniwersytet Narodowy imienia Bohdana Chmielnickiego, Czerkasy - Ukraina
}

STRESZCZENIE. W artykule poddano analizie stałość oraz zmienność przysłów, rozróżniono pojęcia zmienności i transformacji. Normatywna uzualna zmienność nie jest tożsama $\mathrm{z}$ tekstową, okazjonalną zmiennością, lecz stanowi zmienność systemową, wypracowaną w procesie historycznego rozwoju zasobu paremijnego w świadomości mówiących i nie ma dodatkowego ładunku semantycznego, nie uświadamia się przez etnos jako wykroczenie, wykrzywienie tradycyjnego przysłowia. O produktywnej transformacji klasycznych paremii przekonuje dziedziczenie mądrości ludowej, a przekształcenie głębokich treści i cech formalnych takich przysłów świadczy o ich dostosowaniu do nowych społeczno-historycznych warunków i wartości. Resemantyzacja tradycyjnych przysłów jednoznacznie dowodzi ich istotności oraz aktualności, bo przecież jeżeli tradycyjna wypowiedź nie jest zmieniana, nie jest oceniana przez każde nowe pokolenie na swój sposób, staje się nieaktualna 
i nieistotna dla społeczeństwa. Antyprzysłowia częściowo burzą wypracowane przez stulecia stereotypy kosztem komicznego przepracowania ich semantyki.

Słowa kluczowe: przysłowia, antyprzysłowia, zmienność, transformacja, gra językowa, humor

\title{
STABILITY, VARIATION AND TRANSFORMATION OF UKRAINIAN PROVERBS
}

\author{
VALENTYNA KALKO \\ Cherkasy Bohdan Khmelnytsky National University, Cherkasy - Ukraine \\ MYKOLA KALKO \\ Cherkasy Bohdan Khmelnytsky National University, Cherkasy - Ukraine
}

\begin{abstract}
The article considers the problem of proverb stability and modifications, and the difference between the terms modification and transformation. The author draws a conclusion that standard modifications within the national paremiological corpus can not be perceived as textual or occasional modifications. They should be taken as systemic variations within language norms that exist in the mind of native speakers, do not add another semantic meaning and are not recognized by native speakers as proverb deformations. Differences between proverbs (sayings of edifying character, which contain the centuries-old experience of the people) and anti-proverbs (the authors consider anti-proverbs to be the semantic antithesis of proverbs) are highlighted. The authors pay special attention to the study of the semantics of proverbs and their transformants to identify relevant semantic and cognitive characteristics. The productive transformation of classical proverbs convinces of the heredity of folk wisdom, the change in the deep meaning, and the formal plan of the original proverbs testifies to their adaptation to new social and historical conditions and values.
\end{abstract}

Keywords: proverbs, anti-proverbs, proverb modifications, proverb variations, transformation, language game, humor

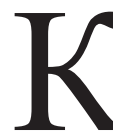

огнітивно-прагматичний напрям вивчення паремійних одиниць передбачає передовсім пояснення й опис принципів і механізмів взаємодії їхньої семантики не лише з універсальними пізнавальними структурами, а й із соціокультурними чинниками, які гнучко реагують на історичні, політичні, економічні, соціальні зрушення, актуалізуючи тріаду «мовна комунікація - свідомість - культура». Прислів'я, з одного боку, належать до стійких мовних одиниць, відтворюваних за традицією, яка й уможливлює їхнє передавання з максимальною точністю як форми, так і змісту, що можуть зазнавати варіювання впродовж багатовікової історії етносу, а з іншого - відкриті для модифікації та трансформації. 
Прислів'я, відображаючи специфіку мислення етносу, зберігаються в пам'яті мовців, відтворюючись у конкретній ситуації спілкування. Їх не творять щоразу заново, а репродукують в усталеній формі як одиниці мови, відомі всій етноспільноті. Для багатьох загальновідомих паремій згадка однієї ключової частини достатня для створення асоціації з усім висловленням. Ця мінімальна пізнавана одиниця є ядром прислів'я [Norrick 1985: 45].

Для паремійного фонду характерна гнучкість норми, яку забезпечує його здатність до саморегуляції відповідно до динамічних змін, що відбуваються в процесі усного побутування. На думку Г. Перм'якова, „єдине, що об'єднує настільки різні тексти в одну мовну категорію, - це відома постійність їхньої форми. Всі вони є стійкими поєднаннями слів" [Пермяков 1988: 15]. Як зауважує О. Кунін, фразеологічна теорія, до предметної царини якої і належать прислів'я, має багато суперечливих моментів, але в питанні стійкості більшість дослідників одностайно вважає, що вона виявлена у відтворюваності фразеологічних одиниць у готовому вигляді [Кунин 1996: 76].

До паремійної системи української мови цілком можна застосувати термін В. Матезіуса „гнучка / еластична стійкість” [Матезиус 1967: 389]. Дослідник уважав, що надана в процесі кодифікації перевага давнішим, а не новим елементам, увиразнює консерватизм літературної мови і в жодному разі не сприяє досягненню бажаної стійкості, а, навпаки, руйнує їі [Матезиус 1967: 392]. Отже, стійкість мовної норми й мовних знаків не заперечують численної варіативності мовних засобів, що є виявом історичних змін, територіальної, стилістичної диференціації тощо. Гнучка стійкість прислів'я допускає варіанти в мовленнєвій реалізації за умови збереження семантичного ядра. Стійкість паремій полягає в їхній здатності зберігати відносну постійність лексичної, граматичної, семантичної структур. Ї̈̈ забезпечують активне і багаторазове використання в мовленні та усталений, стабільний зміст. Стійкості прислів 'їв сприяє насамперед їхня жанрова належність, саме традиція забезпечує їхню відносну сталість. А. Крикманн наголошує, що помилковою є думка, ніби прислів'я - це своєрідні „ready-made utterances”, тобто „скам'янілі кліше” [Крикманн 1978: 101]. Відзначимо, що стійкість і відтворюваність не суперечать, а, навпаки, передбачають протилежну ознаку - варіативність, адже прислів'я можна модифікувати тільки тому, що мовець знає його значення і структуру. Дійсно, паремійні одиниці письмово зафіксовані лише в збірниках, первісно ж вони побутували в усній формі, тому їм властива варіативність: як у формальному, так і в змістовому планах. Однак на глибинному рівні вони містять багато повторюваних елементів, а отже, їм притаманна формально-змістова єдність, пор.: Дитина (дитя) не плаче, мати (матка) не чує (не знає); Як дитя не плаче, у матері думки нема [Прислів'я 1990: 116]; Вовка все в ліс тягне; Вовка як не годуй, а він усе в ліс дивиться; Скільки вовка не годуй, а він у ліс дивиться; Вовча натура в ліс тягне [Прислів'я 1989: 201]. 
Саме навмисна модифікація тексту прислів'їв, наявність варіантів, на думку Г. Перм'якова, не лише суперечать тезі про їхню усталеність, а й навпаки зайвий раз її підтверджують. Їх тільки тому й можна змінювати, що кожен носій мови знає їхню основну, вихідну форму [Пермяков 1988: 15]. У такому разі варіативність прислів'я є підтвердженням його стійкості. Узуальна варіативність відбувається в процесі історичного розвитку паремійного фонду у свідомості мовців і не несе додаткового семантичного навантаження, вона $\epsilon$ підтвердженням ,актуалізації його значення, умовно прийнятого за константу, що моделює комунікативний процес" [Юськів 2013: 72-73].

Здатність до варіювання - глобальна і фундаментальна властивість фольклору, форма вияву самої традиції. Пареміям притаманні зміни, зумовлені передовсім недосконалістю людської пам'яті, яка зберігає їх у закодованому готовому вигляді. в антиномії „усталеність - варіативність” В. Мокієнко вбачає ознаку, яка забезпечує і функціювання, і постійний розвиток паремійної системи [Мокиенко 1989: 10], варіативність не суперечить ідентифікації прислів'я у свідомості індивіда, навіть після значних модифікацій мовець упізнає його. Саме здатність до варіювання - одна з ознак актуальності, значущості, прагматично-фукційної запитаності паремій, адже це не традиційні тиражовані кліше, зміст і форма народних висловлень зазнають переосмислення, оновлення, а отже, пристосовуються до нових умов життя етносу, виявляють зміни в його ментальності.

Варіюванню паремій протиставлена трансформація, у процесі якої відбуваються зміни вищого, складнішого ступеня, що породжують нову номінативну структуру, яка не одразу набуває статусу одиниці фразеологічного рівня. Вона створює нові ряди текстів, тоді як варіативність породжує сюжети/ тексти одного ряду. Утворювані трансформи функціюють як самостійні стійкі висловлення, що мають власне значення, сферу вживання, конотацію. Для трансформованих прислів 'їв В. Мідер запропонував термін антиприслів'я (нім. Antisprichwort, англ. anti-proverb) [Mieder 1985]. На думку дослідника, антиприслів'я - це „пародійні, спотворені чи перекручені прислів'я, у яких знаходить вияв гумористична чи сатирична мовна гра 3 традиційною прислівною мудрістю" [Mieder 2004: 28]. в умовах сьогодення вживання паремій утрачає зв'язок із фольклорною традицією й архаїчними пластами культури, їхня трансформація віддзеркалює сучасні мовні смаки й актуалізує значущі для культури явища [Юськів 2013: 72].

Проблема варіативності й трансформації прислів'їв тісно пов'язана з їхньою знаковою стійкістю. В. Мокієнко антиномію „стійкість - нестійкість” уважає основною діалектичною суперечністю фразеологічної системи [Мокиенко 1989: 20]. Стійкість - це абсолютна, конститутивна ознака паремійних одиниць, яку можна пояснити їхньою трансльованістю. Варіативність - це формальна, факультативна властивість прислів 'їв, умотивована двома ос- 
новними ознаками - розчленованістю форми й семантичною злютованістю. Перша властивість уможливлює досить продуктивну мобільність компонентів, а друга - відносну стабільність значення паремійних одиниць [Мокиенко 1989: 21]. Варіативність паремій можна вважати їхньою відносною властивістю, спричиненою низкою екстралінгвальних чинників (часових, територіальних, соціальних, історичних тощо) та лінгвістичних факторів. Н. Семененко й Г. Шипіцина до власне мовних причин варіювання прислів 'їв зараховують: 1) відсутність безпосередньо сприйнятого зв'язку між прислів' ям і ситуацією, що зумовила його виникнення; 2) наявність різноманітних фокусів спостереження, позицій оцінки ситуації; 3) вторинність тексту прислів'я, яке фіксують на письмі у зв'язку з потребою, тоді як основна форма його побутування усна; 4) пристосування висловлення до потреб дискурсу, комунікативної ситуації [Семененко 2005: 109-110].

Уважаємо, що широке варіювання паремій зумовлюють також наявність узагальненого, колективного адресанта висловлення, хронотопна відносність, синтаксична зумовленість глибинного змісту, концептуальність значення. Наявність варіантів паремійних одиниць засвідчує не стільки невикінчену закріпленість значення за певною формою, скільки граничну узагальненість значення, що в багатьох випадках зменшує питому вагу лексичних засобів вираження семантики. Важливою особливістю варіювання прислів 'їв $€$ їхня обов'язкова співвідносність із прототипним значенням, і у випадках появи різнорівневих варіантів: морфологічних, пор.: Яке дерево, такі й одростки; Яке дерево, такий одросток [Прислів'я 1989: 122]; Великий дуб, та дуплинастий; Великий дуб, та дупловатий; Великий дуб, та дуплистий [Прислів'я 1989: 123]; лексичних, напр.: Не вважай на урожай, а гречку сій; Не вважай на урожай, а жито сій [Прислів'я 1989: 99]; Найшла коса на камінь; Налетіла коса на камінь; Наскочила коса на камінь; Попала коса на камінь; Трафила коса на камінь; Трапила коса на камінь [Прислів'я 1989: 104]; синтаксичних, пор,: Де багато господинь, там хата не метена; Багато господинь, а хата не метена [Прислів'я 1989: 130]; Мани собаку, маючи кияку; Мани собаку, а з рук не пускай кияку [Прислів’я 1989: 190] фіксуємо збереження семантики. Із позицій лінгвосинергетики наявність значної кількості варіантів прислів'я можна пояснити принципом необхідного розмаїття елементів і частин системи, який і сприяє стійкому, динамічному, постійному розвитку паремійного фонду української мови.

Досить важливою $є$ проблема розмежування синонімів і варіантів. На думку Н. Семененко й Г. Шипіциної, перебувати в синонімічних відношеннях можуть тільки прислів'я, побудовані за різними синтаксичними моделями, а синтаксично типові паремії зі схожими засобами морфологічного вираження окремих лексичних компонентів слід кваліфікувати як варіанти [Семененко 2005: 111]. Такий погляд $€$ невмотивованим і неправомірно розширює межі па- 
ремійних варіантів, адже уможливлює, наприклад, об'єднання всіх прислів'їв, побудованих за моделлю Який..., такий, пор.: Який стук, такий грюк [Прислів'я 1989: 301]; Який кухар, такий борш [Прислів'я 1989: 352]; Який день, такий і пожиток [Прислів'я 1989: 77]; Який жнець, такий снопецьь [Прислів'я 1989: 103]; Який косар, така коса [Прислів'я 1989: 105]; Який хазяӥн, такі і слуги [Прислів'я 1989: 129]; Який їхав, таку й здибав [Прислів'я 1990: 80]; Який тато, такий син [Прислів'я 1990: 108]. Однак семантичні відмінності між цими одиницями яскраво унаявнені, їх цілком правомірно визначати як синоніми. На нашу думку, різниця між варіативністю і синонімією зумовлена особливостями концептуалізації: якщо зміна компонентного складу призводить до суттєвої модифікації семантики, то цілком природно кваліфікувати такі форми як різні паремійні одиниці з близьким значенням. Якщо в разі заміщення слів-компонентів відбуваються істотні трансформації, що призводять до значної зміни значення прислів'я і зміни його метафорики, то можемо стверджувати, що такі паремії перебувають у синонімічних відношеннях, пор.: За одного битого двох небитих дають [Прислів'я 1990: 199]; За одного вченого двох невчених дають [Прислів'я 1990: 123] і Перша чарка - на здоров'я, друга на веселощі, а третя - для сварки; Перша чарка - як по льоду, друга - як по меду, а за третю не питай, управляйся, наливай; Перша чарка колом, друга соколом, а решта дрібними пташечками; Перша чарка не брала, друга теж, а третя завела в арешт [Прислів'я 1990: 436]. Мабуть, лексичні заміни, що зумовлюють синонімію, пов'язані з ключовими словами тексту прислів'я, які виражають його основний зміст і мають образно-метафоричне навантаження. Такий компонент називають „ядром прислів'я” [Norrick 1985: 45].

У паремійних знаках досить активно варіюються найбільш значущі й семантично прозорі компоненти, які однозначно передають окремі відтінки значення. Приміром, використання сполук не товариш, не брат в українських прислів'ях - потужний спосіб вказівки на нерівність об'єктів, їхню непоєднуваність, несумісність, перевагу одного над іншим: Шорник ситникові - не товариш; Свиня коню не товариш; Ситий голодному не товариш; Піший кінному - не товариш; Вовк вівиі не товариш; Вовк коневі не товариш; Гусь свині - не товариш; Гусь волові не товариш; Кінний пішому не товариш; Медвідь корові не брат [Прислів'я 1991: 25-26]; Ситий голодному не брат [Прислів'я 1989: 306]. У таких пареміях сполуки не товариш, не брат градуюють, розрізняють, протиставляють, оцінюють предмети, названі попередньою парою компонентів, утворюючи здебільшого прислів'я з глибинним змістом, напр.: Медвідь вовкові не товариш; Кішка миші не товариш; Горщок котлу не товариш чи зрідка з поверхневим, пор.: Ситий голодному не товариш; Піший кінному - не товариш; Горілка вину не товариш.

Можна відзначити, що ті концептуальні царини, які найбільш важливі для життя людини чи з певних причин привертають ії увагу, виявляють більшу 
продуктивність синонімії [Cruse 2002: 507]. Імовірно, що наявність паремійних синонімів у суттєвих для етносу зонах знань $є$ наслідком когнітивої метафори як найістотнішого інструмента пошуку альтернатив. Так, у прислів'ях (1) Вода з вогнем не товариш [Прислів'я 1989: 59]; (2) Кінь волові не товариш [Прислів'я 1989: 162]; (3) Гусь свині не товариш [Прислів'я 1989: 179]; (4) Ситник берднику не товариш [Прислів'я 1989: 272]; (5) Голодний ситому не товариш [Прислів'я 1989: 304]; (6) Горщик котлу не товариш [Прислів'я 1989: 347]; (7) Горілка розуму не товарии [Прислів'я 1990: 438] метафора заперечення не товариш розподіляє, розмежовує, протиставляє, оцінює названу в номінативній структурі пару компонентів. Використання повторюваних елементів - одна з виразних тенденцій у процесі появи синонімії прислів ’їв. Такий процес О. Селіверстова кваліфікує як особливу варіативність, зумовлену тиражуванням паремійних одиниць з використанням кліше [Селиверстова 2017: 181]. Однак, на нашу думку, названі паремійні одиниці утворюють синонімічний ряд, оскільки вони семантично віддалені. Як бачимо, на першому місці названих прислів 'їв вжито той елемент, який із погляду колективного адресанта $є$ найкращим, еталонним, пріоритетним, той, якому другий компонент не підходить, не відповідає. Пари компонентів із різним ступенем невідповідності, поєднуючись у паремійному знакові з елементом не товариш, по-різному реалізують семантику висловлення, пор.: (1) - 'різні, відмінні'; (2-6) - 'не пара, нерівня'; (7) - 'непотрібні; завада'. Отже, заміна метафоричного компонента істотно змінює зміст паремії, іiі естетичну своєрідність, аксіологічне навантаження.

Така широка узуальна варіативність, здатність виявляти синонімічні зв'язки, узагальненість семантики, фактично іiї проєктування на будь-який фрагмент позамовного довкілля уможливлюють певною мірою надання статусу паремійного знака висловленню, побудованому за цією моделлю, що робить його потужним засобом створення оказіональних висловлень - антиприслів'їв, напр.: Австралієць латиноамериканщю - не товариш (Україна молода. 16.10.2014) - про особливості рівня достатку в різних країнах світу; Чому кіпріот німщеві не товариш? (Україна молода. 16.10.2014) - про рівень заробітної плати в країнах Європейського Союзу; Самурай Дракону не товариш (Україна молода. 18.01.2012) - про рецепти новорічних страв японців; Приазовський вовк нам - не товариш! (Україна молода. 19.01.2011) про загрозу поширення вовків на території Північного Приазов’я; Маккартні Узелкову не товариш (Україна молода. 18.06.2008) - про малу кількість відвідувачів боксерського поєдинку Узелков - Шимич через концерт Пола Маккартні в Києві. Отже, чітко простежуємо мовну тенденцію до творення численних трансформованих варіантів паремійної одиниці за моделлю паремійного кліше. Підтвердженням цього є активність функціонування трансформів прислів'я як заголовків медійних статтей, пор.: Комсомол Голодомору 
не товариш (Україна молода. 29.10.2008); Суд порядному менту не товариш? (Україна молода. 07.07.2007); Футбол боксу не товарии, а Донецьк - Києву (Україна молода. 16.11.2006); Язик мові не товариш? (Україна молода. 19.09.2006); Соняшник маку - не товариш (Україна молода. 01.08.2006); Лис корові не товариш (Україна молода. 08.10.2005); Бізнес виборам не товариш? (Україна молода. 21.09.2004); Сумлінність довірі не товариш (Аграрний тиждень.17.04.2013); Прокурор адвокатові не товариш (День. 25.06.2017); Легковажність здоров'ю не товариш (День. 25.04.2014); Пластик природі не товариш (День. 26.04. 2019); Вобла пиву не товариш (Дзеркало тижня. 25.10.2020); Рубль гривні не товариш (Дзеркало тижня. 23.09.2002); Долар гривні не товариш (Дзеркало тижня. 15.10.2014); «Спочка» гривні не товариш (За вільну Україну. 18.09.2003); Суд дитині не товариш (Урядовий тиждень. 27.01.2019).

Саме чітка структура, поширеність і впізнаваність форми традиційних прислів 'їв зумовлюють їхню здатність до трансформації. В. Мідер запам'ятовуваність форми (memorizable form) вважає однією з найважливіших ознак прислів'їв [Mieder 1982: 119]. Етнос упродовж віків вишліфував традиційні форми народної мудрості, наділивши їх довершеною структурною будовою, милозвучністю, римованістю, що, з одного боку, сприяє стійкості цих мовних знаків, а з іншого - зумовлює появу численних трансформованих висловлень. Дійсно, прислів'я зазвичай творять за певними структурно-семантичними моделями, які, на думку Д. Добровольського, можна звести до одного образно-семантичного інваріанта, що схематично відображає відносну регулярність фразоутворювальних процесів [Добровольский 1987: 26]. Саме синтаксична модель прислів'я певною мірою спричинює появу нового висловлення унаслідок повної чи часткової зміни компонентного складу, зумовлюючи докорінну трансформацію змісту і водночас збереження структури. Так, антиприслів'я запозичили в народних висловлень їхню будову за моделями: 1) який..., такий: Який муляр - такий фундамент! Або як легко налаштувати роботу у системі Мій Дім Online (miydimonline.com.ua); Він навіть не спромігся назвати село, про відключення в якому так красномовно розповідав і це не дивно - адже який депутат, такий і представник (Полтавщина. 17.05.2019); Який депутат, такий і помічник. Один одного вартий (Волинь-24. 02.06.2016); Який депутат - такий $і$ закон (Волинь-24. 27.01.2018); Яка зарплата-така й освіma (Дзеркало тижня. 30.09.2011); Яка освіта, така й держава (Педагогічна преса. 25.06.2015); 2) кому..., а кому...: Кому - Голодомор, а кому-ікра: як експрем'єра Франції у Харкові частували у 1933 (www.bbc.com); Кому коронавірус, а кому хочеться ще більшої влади: приклад Орбана в Угорщині (Радіо Сводода. 23.023.2020); Кому мільйон, а кому сто тисяч. Як в Украӥні виплачують компенсації за збитки під час катастроф (Суспільне. 08.02.2021); Кому карантин, а кому й «вільна каса». Тобто, поки ви бідкаєтеся, як воно 
важко в карантин, для когось відкрилося нове вікно можливостей (Демократична сокира. 26.11.2020); 3) було б.., а... знайдеться: Тут читаю, а тут не читаю. Звідси і відомий у народі вислів, - „була б людина, а стаття для неї завжди знайдеться" (mediarnbo.org); Була б людина, а справа знайдеться (Радіо Свобода. 23.02.2021); Було б бажання-стаття знайдеться (newskm. net); Була б дитина і щоденник, а зауваження знайдеться (osvita.ua); 4) де..., там: У результаті місцеві коаліиії формувались за приниипом „де гроші, там і інтереси" (Укрінфом. 12.02.2020); Але хто в Украйні не знає: де гроші там... корупція. Ну такі реалії, нічого не поробиш (prostir.ua); Де совок там і сміття (Погляд. 28.07.2016); По правді, де Зеленський, там можна сміятись. Навіть тут (gordonua.com); 5) краще..., ніж: Краще перехворіти, ніж щелитися (zaxid.net); Краще хаос, ніж застій (День. 21.03.2021); Краще хороший бос, ніж хороша компанія (hr-security.ua); Краще пузо від пива, ніж горб від роботи; Краще переспати, ніж недоїсти (vn.20minut.ua); Краще запобігти, ніж захворіти (uzhnu.edu.ua). Наші спостереження доводять, що досить популярними є українські антиприслів'я побудовані на грунті бінарних моделей, що, на думку В. Мідера й А. Литовкіної, дають змогу за однією формулою закріпити різні образи, ідеї [Mieder, Litovkina 1999: 5].

3 одного боку, антиприслів'я актуальні й злободенні, оскільки відображають сучасні реалії життя етносу, з іншого ж - вони недовгочасні, семантично значущі лише в певному контексті, бо зазвичай відображають тимчасові політичні, економічні, спортивні та інші події сьогодення. Трансформацію паремій автори використовують, намагаючись освіжити їхній зміст, пристосувати до конкретної ситуації, використовуючи для цього різні стилістичні прийоми, що посилюють експресивність, емоційно-оцінні, функціональні конотації, а також змінюють глибинний і поверхневий зміст традиційного прислів'я. Здатність паремії до трансформації залежить від багатьох чинників, основними з яких вважаємо специфіку глибинного змісту, співвідношення між компонентами значення і форми, ступінь мотивованості семантики, ізоморфізм форми та змісту. Саме трансформація прислів 'їв і як наслідок поява антиприслів 'їв засвідчує їхню популярність і прецедентність, адже нові висловлення створені за традиційними моделями, за якими адресант може швидко розпізнати прототип, оцінити гумор, пор.: За двома зайиями поженешся - жодного не піймаєш - 'намагання одночасно здобути успіх у кількох справах одночасно приречене на поразку’ і Акиія зараз, а поліс треба буде через місяиь? «За двома зайцями поженешся, двох спіймаєш!» Сміливо оформлюйте автоцивілку зі знижкою наперед (hotline.finance); За двома зайиями поженешся, ще й третього спіймаєш! (vambud.com.ua); За двома зайчями поженемся, жодного кабана не спіймаєш; За двома зайиями поженешся, від єгеря по морді отримаєш; За двома зайцями поженешся, трьох зайців зловиш; $3 а$ двома зайцями поженешся, хоч одного зловиш (zkan.com.ua). 
Трансформація паремій здебільшого трапляється в публіцистичних текстах, де вона $є$ засобом привертання уваги читача, мовною грою, пор.: Хто сіє в вітер, той пожне дулю (Голос України. 15.05.2021); Око за око, плюс зуб за зуб, плюс кров за кров, дорівнює ум за розум (Голос України. 15.05.2021); Узаможного гроші в капшуку, у бідного - в голові (Голос України. 15.06.2021). Унаслідок такого перетворення постають антиприслів'я, які, на відміну від повчальності паремій, спрямовані на висміювання й руйнування моральних і мовних норм [Вальтер 2004: 7], а тому є одним із засобів вираження сміхової культури, напр.: Скажи мені, хто твій друг, і обидва відпочиньте; Навчання - світло, а ти відпочинь; Робота не вовк, можна і відпочити (social.org. ua); Семеро одного не чекають, якщь він не дуже важлива людина; У ногах правди немає, якщо ноги не в роті; У тихому болоті чорти топляться (myplanet.com.ua).

Як одиниці культурного знання прислів'я все більше зазнають креативного перероблення, оскільки домінантою сучасного життя є сміхова культура. Не лише карнавалізація мови засобів масової інформації та Інтернету, а й повсякденного побутового спілкування призвели до того, що прислів'я активно потрапляють у поле ігрових маніпуляцій. Структурно-семантична парадоксальність і експресивність паремій і фразем, на думку В. Мокієнка, $€$ природним матеріалом для мовної гри, а різні способи їхньої трансформації підвищують потенціал мовного обігрування [Мокиенко 2012: 49]. Мовну гру розуміємо як свідоме маніпулювання мовою, побудоване якщо не на аномальності, то, принаймні, незвичному використанні мовних засобів [Санников 1999: 37], В. Санников процес перефразування прислів 'їв, реалізований в абсурді, парадоксі й іронії, уважає одним із її виявів [Санников 1999: 4]. Мовна гра в процесі творення антиприслів 'їв має вияв на таких рівнях: 1) фонетичному: Зробив тіло - гуляй сміло (scoolbylife); Друг пізнається в біде (mobildi.narod); 2) лексичному: Зустрічають по одягу - проводжають по номерках $У$ гардеробі; Апетит приходить під час довгої відсутності їжі в шлунку (myplanet.com.ua); Язик до кілера доведе! (www.gumor.org); в здоровому тілі - здоровий біолог! (univ.kiev.ua); 3) синтаксичному: Щодо теми «РосУкрЕнерго» Діма Медведєв мовчав, як риба об лід (gordonua.com); Здоров'я не купиш, ним можна лише розплачуватися (sites.google.com)

Трансформація паремій також представлена в художніх творах, пор.: Приповідку «Вовка ноги годують, а християнина - руки» він перекрутив на: «Вовка ноги годують, а християнина - язик» і старався довести, щзо то свята правда (В. Сенько); - Шкутильгай звідси подалі. а то подзвоню в мілічџію. Каторжанин. Дружба дружбою, а злочинцям - поворот од дверей. i Ніну забудь. Вона моя наречена (О. Бердник). Такі висловлення потребують ідентифікації з боку читача, вимагають від нього обізнаності із паремійним фондом, необхідної комунікативної компетенції. 
Трансформація паремій у художніх і публіцистичних текстах передовсім відбувається внаслідок зміни лексичного складу, що спричинює модифікацію глибинного змісту: Дружба дружбою, а мотори нарізно (Український тиждень 13.02.2014); - Дружба дружбою, а закон, братці ви мої, закон - нерушимий. Та що я з тобою патякаю? Не знаю, чого ти прийшов (О. Бердник), пор.: Дружба дружбою, а служба службою [Прислів'я 1991: 23]; Після иих слів «слуги божсго» розумісш, що не такий страшний чорт, як протоісрей Чаплін! (Голос України. 04.01.2020); Не такий страшний доцент, як його малюють (Українська правда. 01.09.2016); Не такий страшний коронавірус, як його малюють (Тернопільські новини. 24.02.2020); Hi, не боюся я злиднів, бо я вже скоштував гіркої й бачу, що не такий вже «страшний чорт, як його малютки». Працювати я можу, а доведеться викручуватись, - буду викручуватись. Хвороба? - Від неї ніхто не застрахований на всій земній кулі. Чого ж мені боятися ії в Австралії, коли б вона могла зробити мені таку саму прикрість в Полтаві чи в Монахині? (Василь Королів-Старий), пор.: Не такий страшний чорт, як його малюють [Прислів'я 1990: 409]; Так закінчилася спроба повернути порядок речей: $\boldsymbol{x т о ~ н е ~ п р а ц ю е ~ - ~ т о и ̆ ~ с о л о д к о ~}$ їсть, а хто працює - їсть з милості того, хто не працює (М. Білкун), пор.: Хто не працює, той не їсть [Прислів'я 1989: 290].

Отже, поряд зі стійкістю як визначальною рисою паремій їм водночас притаманні варіативність і трансформація. Нормативна узуальна варіативність - це не текстова, оказіональна варіативність, а системна, мовна, яка відбулася в процесі історичного розвитку паремійного фонду в свідомості мовців і не несе додаткового семантичного навантаження, не усвідомлена етносом як спотворення, викривлення традиційного висловлення. Прислів'я нерозривно пов'язані з контекстом у структурному й семантичному планах, саме вплив середовища на паремію може спричинити трансформацію, грунтовану здебільшого на тісному зв'язку іiї семантики й контексту. Передумову трансформації прислів 'їв убачаємо в обізнаності мовця не лише зі значенням і формою: сприймаючи прислівний трансформ адресант зіставляє, порівнює, протиставляє його узуальному традиційному висловленню, і в результаті цього сприймає, інтерпретує й розуміє інформацію. Варіанти паремії існують в пам'яті мовця поза межами контексту, а трансформація завжди пов'язана 3 конкретним контекстом, зорієнтована на досягнення комунікативного ефекту, визначені стилістичні прийоми, актуалізацію каламбурного обігравання. Трансформації паремій - це операції з уже готовими мовними знаками, у результаті чого створюють нові мовні одиниці, зорієнтовані на комунікативну інтригу, когнітивний дисонанс. Такі модифікації класичного прислів'я дають змогу освіжити зміст паремії, пристосувати ії до нових викликів сьогодення. Перспективу подальших студій вбачаємо в удокладненні опису прийомів створення антиприслів 'їв української мови. 


\section{Список використаної літератури}

Вальтер Х., Мокиенко В.М., Прикольный словарь (антипословицы и антиафоризмы), Москва: Олма Медиа Групп, 2004.

Добровольский Д.О., Структурно-типологический анализ фразеологии и фразеографическая параметризачия (на материале русской и германской идиоматики), [в:] „Фразеологизм и его лексикографическая разработка”, Минск: Наука и техника, 1987, с. 24-26.

Крикманн А., Некоторые аспекты семантической неопределенности пословицы, [в:] „Паремиологический сборник: пословица, загадка (структура, смысл, текст)”, сост. Г.Л. Пермяков, Москва: Наука, 1978, с. 82-104.

Кунин А.В., Курс фразеологии современного английского языка, Москва: Высшая школа, Дубна: Изд. центр „Феникс”, 1996.

Матезиус В., О необходимости стабильности литературного языка, [в:] Пражский лингвистический кружск, сборник статей, сост., ред. и предисл. Н.А. Кондрашова, Москва: Прогресс, 1967, с. 378-399.

Мокиенко В.М., Мотивация демотивируемого: проблемы анализа внутренней формы фразеологии, [в:] „Актуальные проблемы мотивологии в лингвистике XXI в.”, под. ред. О. Блиновой, Томск, Изд-во Томского унивеситетаб, 2012, с. 40-50.

Мокиенко В.М., Славянская фразеология, Москва: Высшая школа, 1989.

Пермяков Г.Л., Основы структурной паремиологии, Москва: Наука, 1988.

Санников В.3., Русский язык в зеркале языковой игры, Москва: Языки русской культуры, 1999.

Селиверстова Е.И., Пространство русской пословищь. Постоянство и изменчивость, Москва: Флинта, 2017.

Семененко Н., Шипицына Г., Русская пословица: функции, семантика, системность, Белгород: Изд-во БелГУ, 2005.

Юськів Б., Паремійна картина світу: проблеми дослідження, [в:] „Studia Ukrainica Posnaniensia", 2013, z. I, s. 67-73.

Cruse D. Alan, Paradigmatic Relations of Exclusion and Opposition II: Reversivity, [in:] „Lexikologie: Ein internationales Handbuch zur Natur und Struktur von Wörtern und Wortschätzen: Lexicology: An international handbook on the nature and structure of words and vocabularies", ed. David A. Cruse, Berlin: De Gruyter, 2002, vol. 1, p. 507-510.

Mieder W., Antisprichwörter, Wiesbaden: Verlag für deutsche Sprache, 1982.

Mieder W., Popular views of the proverb, [in:] „Proverbium”, 1985, nr 2, p. 109-143.

Mieder W., Proverbs: A Handbook, Westport: Greenwood Press, CT, 2004.

Mieder W., Litovkina A. T., Twised Wisdom: Modern Anti-Proverbs, Burlington: The University of Vermont, 1999.

Norrick N.R., How proverbs mean: semantic studies in English proverbs, Berlin-New York: Mouton, 1985. 


\section{Список використаних джерел}

Бердник О., Зоряний корсар, Київ: Радянський письменник, 1971.

Білкун М., Багато, багато, багато золота ..., Київ: Молодь, 1975.

Королів-Старий Василь, Чмелик, Прага: Друкарня „Політики”, 1920.

Прислів'я та приказки: Природа. Господарська діяльність людини, упоряд. М.М. Пазяк, Київ: Наукова думка, 1989.

Прислів'я та приказки: Людина. Родинне життя. Риси характеру, упоряд. М.М. Пазяк, Київ: Наукова думка, 1990.

Прислів'я та приказки: Взаємини між людьмит упоряд. М.М. Пазяк, Київ: Наукова думка, 1991.

Сеньо М., Біля райських воріт: Збірник атеїстичного фольклору украӥнського населення Kapnam, Ужгород: Карпати, 1980.

\section{Spysok vykorystanoi literatury [References]}

Valter H., Mokiyenko V.M., Prikolnyy slovar (antiposlovitsy i antiaforizmy) [Cool dictionary (anti-proverbs and antiaphorisms)], Moskva: Olma Media Grupp, 2004.

Dobrovolskiy D.O., Strukturno-tipologicheskiy analiz frazeologii i frazeograficheskaya parametrizatsiya (na materiale russkoy i germanskoy idiomatiki) [Structural and typological analysis of phraseology and phraseographic parametrization (based on Russian and German idioms)], [v:] „Frazeologizm i yego leksikograficheskaya razrabotka”, Minsk: Nauka i tekhnika 1987, s. 24-26.

Krikmann A., Nekotoryye aspekty semanticheskoy neopredelennosti poslovitsy [Some aspects of the semantic uncertainty of a proverb], [v:] „Paremiologicheskiy sbornik: poslovitsa, zagadka (struktura, smysl, tekst)” сост. Г.Л. Пермяков, Moskva: Nauka, 1978, s. 82-104.

Kunin A.V., Kurs frazeologii sovremennogo angliyskogo yazyka [Course of phraseology of modern English], Moskva: Vysshaya shkola, Dubna: Izd. tsentr „Feniks”, 1996.

Matezius V., O neobkhodimosti stabilnosti literaturnogo yazyka [On the need for stability of the literary language], [v:] „Prazhskiy lingvisticheskiy kruzhok”, Moskva: Progress, 1967, s. 378-399.

Mokienko V.M., Motivatsiya demotiviruyemogo: problemy analiza vnutrenney formy frazeologii [Motivation of the demotivated: the problem of analyzing the internal form of phraseology], [v:] „Actual problems of motivology in linguistics of the XXI centurys”, под. ред. О. Блиновой, Tomsk, Изд-во Томского унивеситетаб, 2012, s. 40-50.

Mokiyenko V.M., Slavyanskaya frazeologiya [Slavic phraseology], Moskva: Vysshaya shkola, 1989.

Permyakov G.L., Osnovy strukturnoy paremiologii [Fundamentals of structural paremiology], Moskva: Nauka, 1988.

Sannikov V.Z., Russkiy yazyk v zerkale yazykovoy igry [Russian language in the mirror of a language game], Moskva: Yazyki russkoy kultury, 1999. 
Seliverstova Ye., I. Prostranstvo russkoy poslovitsy. Postoyanstvo i izmenchivost [The space of the Russian proverb. Persistence and Variability], Moskva: Flinta, 2017.

Semenenko N., Shipitsyna G., Russkaya poslovitsa: funktsii, semantika, sistemnost [Russian proverb: functions, semantics, consistency], Belgorod: Izd-vo BelGU, 2005.

Yuskiv B., Paremiyna kartyna svitu: problemy doslidzhennya [Paremia picture of the world: the problems of investigation], [v:] „Studia Ukrainica Posnaniensia”, 2013, z. I, s. 67-73.

Cruse D. Alan, Paradigmatic Relations of Exclusion and Opposition II: Reversivity, [in:] „Lexikologie: Ein internationales Handbuch zur Natur und Struktur von Wörtern und Wortschätzen: Lexicology: An international handbook on the nature and structure of words and vocabularies", ed. David A. Cruse, Berlin: De Gruyter, 2002, vol. 1, p. 507-510.

Mieder W., Antisprichwörter, Wiesbaden: Verlag für deutsche Sprache, 1982.

Mieder W., Popular views of the proverb, [in:] „Proverbium”, 1985, nr 2, p. 109-143.

Mieder W., Proverbs: A Handbook, Westport: Greenwood Press, CT, 2004.

Mieder W., Litovkina A. T., Twised Wisdom: Modern Anti-Proverbs, Burlington: The University of Vermont, 1999.

Norrick N.R., How proverbs mean: semantic studies in English proverb, Berlin-New York: Mouton, 1985.

\section{Spysok vykorystanykh dzherel \\ [References]}

Berdnyk O., Zoryanyy korsar [Star Corsair], Kyiv: Radyanskyy pysmennyk, 1971.

Bilkun M., Bahato, bahato, bahato zolota... [Many, many, many gold ...], Kyiv: Molod, 1975. Koroliv-Staryy Vasyl, Chmelyk [Chmelyk], Praha: Drukarnya „Polityky”, 1920.

Pryslivya ta prykazky: Pryroda. Hospodarska diyalnist lyudyny [Proverbs and sayings: Nature.

Human economic activity] / uporyad. M.M. Pazyak, Kyiv: Naukova dumka, 1989.

Pryslivya ta prykazky: Lyudyna. Rodynne zhyttya. Rysy kharakteru [Proverbs and sayings:

Man. Family life. Character traits], uporyad. M.M. Pazyak, Kyiv: Naukova dumka, 1990.

Pryslivya ta prykazky: Vzayemyny mizh lyudmy [Proverbs and sayings: Relationships between people], uporyad. M.M. Pazyak, Kyiv: Naukova dumka, 1991.

Senko M., Bilya rayskykh vorit [At the Gates of Paradise], Uzhhorod: Karpaty, 1980. 